\title{
УКРАЇНСЬКА ВІЙСЬКОВА ТЕМАТИКА НА СТОРІНКАХ ЖУРНАЛУ «УНІВЕРСУМ» (1993-2018)
}

\author{
Вікторія Романчук \\ Всеукраїнський журнал політології, футурології, \\ економіки, науки та культури «Універсум», \\ a/c 2994, 79017, Львів, Україна, \\ e-mail: viktoriya.romanchuk7@gmail.com
}

У статті проаналізовано публікації на сторінках журналу «Універсум», присвячені проблемі становлення і розвитку Збройних Сил України - надзвичайно важливої складової державності, які порушують питання воєнної безпеки, висвітлюють актуальні проблеми мілітарної політики, реформування ЗСУ, дають оцінку стану українського війська на різних етапах державного будівництва.

Ключові слова: Збройні Сили, боєздатність, військова доктрина, криза, реформа, роззброєння.

Вступ. Після відновлення державності у 1991 році становлення Збройних сил України відбувалося в складних політичних та економічних умовах. Незважаючи на спротив колишньої метрополії ЗСУ таки були створені. Сьогодні вже можна зробити однозначний висновок: Українське військо є вагомим фактором стабільності й безпеки в Свропі. Проте тривалий час політичне керівництво Української держави належним чином не усвідомлювало вкрай важливої ролі збройних сил у державотворчому процесі, а під час президентства Віктора Януковича відверто перешкоджало будівництву ЗСУ та організації ефективного безпекового чинника. Постсовєтська еліта в Україні, у тому числі й військова, не відчувала своєї причетності до української військової традиції. Ними, по суті, було зігнороване непроминальне застереження видатного українського державника В'ячеслава Липинського: «Спинний хребет кожної державної, а отже, й державно-демократичної організації - армія... Головне, річ не в тім, що нам потрібна армія, - бо це розуміють усі, - а в тім, як нам створити таку армію, яка б захищала нашу державу, а не руйнувала ї; була їі опорою, а не найбільшою для неї небезпекою».

Постановка проблеми. Свого часу С. Петлюра у статті «Завдання української військової літератури» (ч. 1 журналу «Табор» за 1923 р.) порушив цілу низку важливих державних проблем. В останніх розділах праці йдеться про армію як важливий елемент держави. Він, зокрема, наголошував на тому, що ширина проблеми взаємин держави і війська та взаємодії військових і політичних чинників вимагає спеціальної творчої уваги з боку представників нашої військової науки та літератури й чекає все-

(C) Романчук В., 2018 
бічного наукового освітлення в монографіях і розвідках. Ці думки С. Петлюри, що стосуються захисту української державності, будівництва армії і в цьому контексті завдань військової літератури (йдеться і про фахову літературу, і про друковані органи мілітарної думки, тобто, про журналістику) актуальні й сьогодні, через 95 років, в умовах російсько-української війни.

Сучасні українські мас-медіа так чи інакше порушували тему військового будівництва і безпеки держави, однак їм значною мірою бракувало системності у висвітленні проблем ЗСУ. Лише після брутальної, всупереч міжнародному праву, анексії Криму Російською Федерацією в березні 2014 року ситуація з аналізом проблем Збройних сил України у засобах масової комунікації помітно поліпшилась.

Серед періодичних видань журнального типу, які спеціалізуються на військовій тематиці, слід назвати такі часописи як «Воєнна історія» (заснований 2006 року) та «Офіцер України» (заснований 2011 року). 3-поміж «цивільних» часописів лише «Універсум» упродовж своєї чвертьстолітньої історії (заснований 1993 року) засадничо і системно приділяв увагу проблемам ЗСУ. По суті, видання не оминуло увагою жодну з ключових проблем, пов'язаних із будівництвом сучасних Збройних сил України.

Слід відзначити принципову державницьку позицію «Універсуму» в питаннях захисту національних інтересів. Активно реагуючи на соціально-політичні процеси в Україні, радикальні зміни у багатьох сферах життя, журнал разом з тим постійно аналізував ситуації, які тією чи іншою мірою торкалися проблеми безпеки держави, військового будівництва. Військова тематика постійно перебувала в нерозривному зв’язку з реаліями сьогодення - подіями та фактами.

Видання прагнуло концентровано віддзеркалювати воєнно-політичну позицію професіоналів, надаючи свої сторінки авторитетним авторам, котрі аргументовано боронили високі ідеали незалежної України в мілітарній сфері.

Серед них генерали і адмірали, офіцери ЗСУ, науковці, які добре орієнтувалися у військовій тематиці, розуміли значення армії в державному будівництві і яких непокоїла складна ситуація в Збройних силах України. В числі постійних авторів журналу генерал-полковник Костянтин Морозов, генерал-лейтенанти Олександр Скіпальський, Олексій Лавренюк і Петро Процик, віце-адмірали Борис Кожин і Володимир Безкоровайний, полковники Петро Костюк і Віталій Лазоркін, заступник Секретаря РНБОУ, академік НАНУ Сергій Пирожков, директор Центру дослідження армії, конверсії та роззброєння Валентин Бадрак та інші.

Вони не лише демонстрували оригінальне бачення розв'язання проблем творення держави 3 погляду військовиків, але й намагалися привернути увагу державних чинників до складних проблем військового будівництва, неодноразово ведучи публічну полеміку з владою, політичними опонентами.

Зазначимо, що упродовж останніх років (після запровадження на кафедрі української преси ЛНУ ім. І. Франка спеціалізації «Воєнна журналістика») журнал «Універсум» був об’єктом дослідження у кількох магістерських роботах, які випускники факультету успішно захистили.

Мету статті ми вбачаємо в тому, щоб з'ясувати основні проблеми, що їх висвітлював і аналізував «Універсум» упродовж 1993-2018 років, динаміку воєнного дискурсу, рівень фаховості аналізу проблем, пов'язаних із будівництвом армії, ідейно-концептуальні засади висвітлення мілітарної тематики. 
Виклад матеріалу. Вперше до військової теми журнал звернувся на початку 1994 року. У січнево-лютневому числі було надруковане інтерв’ю 3 екс-міністром оборони генерал-полковником Костянтином Морозовим «Я щиро повірив в ідею державної незалежності України». Герой ексклюзиву поділився своїми думками про початки будівництва ЗСУ: «Я дуже чітко усвідомлював (і сьогодні продовжую так само думати), що маємо виняткову історичну можливість збудувати незалежну українську державу. Звичайно, є люди, які дотримуються іншої думки. <...> Але ми були просто зобов'язані показати нашим підлеглим, що українське військо - це не колишня Радянська Армія» [35].

Через двадцять років «Універсум» надрукував рецензію Дмитра Павличка на книжку споминів першого міністра оборони України Костянтина Морозова «Моя українізація», яка, на думку знаного поета і політика, назавжди увійде в українську та світову історію як послання до майбутніх поколінь нашого народу: «К. Морозов як міністр оборони розумів, що до його обов'язків належить не тільки організація готовності Збройних сил держави до відсічі агресорові, а й стратегічно-військова передбачливість, яка наказувала робити все можливе, щоб ослабити ворога ще до того, як він нападе. Ця геніальна передбачливість міністра явила себе в його поглядах на розподіл Чорноморського флоту СРСР між Україною та Росією» [40].

1995 року Костянтин Морозов застерігав: «Незважаючи на мирну ситуацію довкола України, наша держава мусить мати свої збройні сили. I якщо ознакою державності є армія, то вона має бути армією, а не просто групою найманих військовиків, яких держава годує. Ліпше мати невелику кількісно армію, проте професіональну, боєздатну, спроможну давати збройну відсіч у будь-який час» [36].

«Хто розвалює нашу армію?» Під таким промовистим заголовком «Універсум» надрукував інтерв’ю з начальником кафедри стратегії Академії Збройних Сил України, генерал-лейтенантом Олексієм Лавренюком, колишнім начальником управління підготовки 3С та інспекції, заступником начальника Генерального штабу [26].

Вже на початку розмови генерал чітко задекларував свою патріотичну позицію: «Сьогодні військова доктрина нічого не значить для держави, вона - формальна і не кличе народ України до захисту своєї держави. В ній не передбачено - від кого захищати державу, яке треба мати військо, яке озброєння». Олексій Лавренюк з болем констатує: «Все, що робиться в Україні, дуже чітко сплановано: демонтувати Збройні Сили, демонтувати військово-промисловий комплекс і найголовніше - дискредитувати Збройні Сили та генералітет, прищепити людям неповагу до армії, зрівняти генералів з офіцерами, офіцерів - із сержантами і солдатами. <..> Збройні Сили України, які маємо сьогодні, не $є$ національною, народною армією, а саме така армія потрібна нашш державі. Я наполягаю, щоб армія була етнічною, щоб у військових вузах навчалися переважно українці, командні пости займали українці і уряд був український».

Олексій Лавренюк наголошував: «Ми не повинні говорити про Збройні Сили України. Це помилка. Слід говорити про військову організацію нашої держави<...>. Ніхто наразі не знає, коли і де доведеться воювати».

Костянтин Морозов, уже як директор Центру дослідження проблем української державності, проаналізував військове будівництво в Україні 1991-1995 рр. Автор визначив періоди військового будівництва, оцінив основні події, дослідив стан Збройних сил як наслідок політичних умов їхнього формування. Екс-міністр оборони по- 
рушив актуальні проблеми військової реформи і зробив важливі висновки. Один 3 них: «Практична взаємодія з питань військового будівництва із Заходом не повинна сприйматися як приниження нашої гідності, це реальний відхід від минулого, що і сьогодні своїм впливом перешкоджає нам бути державою» [37].

У статті Миколи Олексіїва і Олександра Козакевича «Тиха війна» [39] йдеться про мало не відкриту підготовку Росією анексії Криму, про потаємні пружини й важелі, які спрацювали згодом, у лютому 2014 року. Кілька фрагментів цього дослідження дають уявлення про «стратегічного партнера» і методи його діяльності: «Зоною найпильнішої уваги бійців «невидимого фронту» одного з наших стратегічних партнерів ось уже кілька років є Крим, Севастополь, Причорноморський регіон. $<$...> Росія зробила все, щоб перешкодити будівництву, становленню ВМС України. Велике значення у вирішенні цього завдання відводиться розвідці Чорноморського флоту. <..> Антиукраїнська спрямованість діяльності розвідки ЧФ засвідчує, що вона наполегливо втягувала й продовжує втягувати Чорноморський флот у «холодну війну» не тільки проти ВМС України, але й проти Української держави. Багато фактів також переконливо свідчать, що в Росії, Криму і Севастополі, на ЧФ є сили, дуже зацікавлені в тому, щоб ця війна з холодної в будь-який момент могла перерости у збройний конфлікт».

Політичний оглядач Національної телекомпанії України Борис Гривачевський дав читачам «Універсуму» розгорнуту оцінку спільним українсько-американським навчанням «Сі-Бриз-97» [8]. Для рутинної державної служби служби новин це було різко, несподівано, безкомпромісно, але водночас патріотично. «Дамокловим мечем над тілом розтерзаної економічними негараздами Української держави, напевно, ще довго висітиме чи двоголовий орел, чи червоно-коричневий коршак. Висітиме, доки в собі не вб'ємо раба, не будемо крок за кроком утверджувати свою державну могутність, відчуваючи партнерське плече європейських держав», - резюмував Борис Гривачевський.

«Під прапором Сагайдачного і Хоткевича» - під таким заголовком вміщене інтерв’ю кореспондента «Універсуму» в Польщі Володимира Прядка з керівником відділу збройних традицій Війська Польського полковником Тадеушем Кжонстеком, ініціатором створення польсько-української спільної військової частини, який добре розуміє важливість мілітарної співпраці між двома країнами [45].

Підполковник Михайло Требін з Харківського військового університету в своєму дослідженні «Принципи життєдіяльності Збройних сил України» [60] робить висновок, що основними духовними принципами життєдіяльності армії мають бути: єдність національно-історичних і національно-патріотичних аспектів у системі духовних цінностей війська; функціонування в збройних силах широкої системи інформаційно-пропагандистської, виховної та культурно-освітньої діяльності тощо.

У публікації «Ще один шанс примирення» [46] Володимир Прядко розповів про історію створення Міжнародного мілітарного Корпусу, до якого увійшли військові з Данії, Німеччини та Польщі. Про те, як функціонує багатонаціональний підрозділ, повідомив заступник начальника Штабу генерал дивізії Едвард Пєтжик. На його думку, створення такого військового з'єднання - це новий досвід, новий виклик, новий шанс. Це розширення зони стабілізації в конкретному регіоні Європи.

У статті «Система європейської безпеки і національні інтереси України» [38] Костянтин Морозов фахово проаналізував роль НАТО як військово-політичного со- 
юзу, його оборонну спрямованість. Він звернув увагу на те, що стверджувати про «агресивну спрямованість» Альянсу щодо України немає підстав оскільки його військовій організації ніколи не був притаманний наступальний характер, на відміну від військових угруповань Організації Варшавського Договору. У статті детально описано принцип цивільного контролю за органами управління НАТО, відзначено демократичні принципи колегіальності та рівноправності при підготовці рішень, дотримання принципу існування національної приналежності армій.

Олег Селюк в аналітичній розвідці «Третє роззброєння» [52] звертає увагу на те, що відомі українські політики Володимир Горбулін, Олег Зарубінський та Борис Андресюк визнали, що якби Україна зберегла ядерну зброю, то ні про яку Тузлу не могло би бути й мови: «Саме Тузла продемонструвала, що Україна має небезпечно слабкі для неї Військово-морські сили. І ось тепер замість збільшення кількості бойових кораблів їх збираються скоротити до 16 одиниць, тобто в декілька разів. I це маючи понад 1500 кілометрів морських кордонів!»

Голова Комітету ВР України з питань національної безпеки і оборони Борис Андресюк у статті «Військова організація України: цивільний демократичний контроль» [1] вказує на пріоритети військового будівництва: «... у силових міністерствах та відомствах склалася практика, коли відставка першої особи традиційно тягне за собою звільнення не лише управлінської верхівки відповідної структури, але і середньої ланки управління. Це практично призводить до гальмування процесів реформування Збройних сил України та інших складових військової організації нашої держави. <...> Треба законодавчо закріпити перелік адміністративних посад у Міністерстві оборони та інших структурах військової організації, що відповідають за служби забезпечення, планування та тилу, які повинні посідати цивільні особи».

Сергій Пирожков, заступник Секретаря РНБОУ, директор Національного інституту проблем міжнародної безпеки, академік НАНУ в матеріалі «Актуальні проблеми реформування сфери безпеки і оборони України» [41] наголошує, що Україна протистоїть глобальним викликам безпеки спільно з іншими європейськими державами. Автор відзначає докорінні зміни у внутрішньополітичній ситуації в Україні після президентських виборів 2004 року, що дозволяє суттєво поглибити взаємини України з партнерами як на Заході, так і на Сході.

Володимир Безкоровайний - заступник міністра оборони, командувач Військово-морськими Силами України у 1993-1996 рр., кандидат військових наук, віце-адмірал запасу у своїй статті «Угоди про Чорноморський флот мають бути переглянуті» [4] звертає увагу на те, що «РФ підтримує регіональну напругу в Криму і Севастополі для витискання з України подальших політичних і економічних поступок». Автор переконаний, що така поступливість, запроваджена Леонідом Кравчуком в українську дипломатію як принцип російсько-українських відносин, перетворилась на політичну хворобу України.

Цей же автор у розлогому дослідженні «Чорноморський флот Росії в Україні» [5] непокоїться, що російська сторона планує приступити до розв'язання проблеми базування ЧФ РФ тільки після закінчення терміну його перебування в Україні. Ще одна проблема, на яку Володимир Безкоровайний звертає увагу: «Існує ще одне, найважливіше питання: чи має ЧФ РФ ядерну зброю на території України? Відповіді на це питання українська сторона не одержала. У цьому зв'язку в мене як фахівця-ядер- 
ника виникають серйозні причини для занепокоєння, тим більше, що Росія заблокувала можливість верифікації Україною усіх видів зброї, у тому числі і ядерної».

Генерал-лейтенант Олександр Скіпальський, екс-начальник Головного управління розвідки Міністерства оборони чітко артикулює: «Національна безпека - це далеко не гонитва передусім за шпигунами й терористами, агентура й викрадення секретів. Національна безпека визначається міцною економікою, сильною, спроможною рішуче захищати суверенне існування владою, виразно визначеною зовнішньою політикою і пріоритетами свободи та громадянського суспільства у внутрішньому житті. Але в основі їі лежить національна самосвідомість і патріотизм. Як на мене, майже півтора десятиліття української незалежності були катастрофічно руйнівними для цих якостей... Спецслужби - це інструмент національної безпеки. Рішення по використанню напрацьованих ними даних ухвалюють політики. А у них своя логіка і мотивація. І вони, як це не прикро, не вміють і не хочуть слухати» [54].

Позиція Олександра Скіпальського, задекларувана ним 2005 року, багато в чому прояснює причини нинішніх негараздів у сфері безпеки: «У нас в ейфорії на відповідальні посади прийшли люди, далекі від проблематики спецслужб, в тому числі і секретар РНБОУ... Не може бути на посаді, що завжди перебуває у полі зору іноземних спецслужб, людина, яку легко ловити на гачок <...> В основі діяльності спецслужб, i це аксіома, лежать два критерії - патріотизм і професіоналізм. I Головне управління розвідки МО України, мені здається, тому і потрапило під приціл знищення. Ми відбирали офіцерів, які йшли в українську розвідку свідомо, а не перебіжчиками. $<$...> Україна - єдина з країн СНД, яка змогла створити дієздатну військову розвідку. За шість годин до бомбардувань НАТО Югославії ми доповідали про це українському керівництву. Нам не повірили. Політики не замислювалися, яким чином Крим уникнув військових конфліктів з участю ЧФ РФ (а такі спецоперації готувалися: завозилася зброя, наркотики). <..> Безумовно, для наших потенційних суперників, конкурентів, та й ворогів сильна, цілеспрямована і усюди проникаюча українська розвідка не потрібна. <...> Ще в 1993 році в Україні був створений Комітет з питань розвідки при Президентові України, який зараз не працює, хоча саме він може і повинен координувати розвідувальну діяльність» [53].

Василь Лаптійчук, директор Інституту Росії (Україна), відомий спеціаліст 3 українсько-російських стосунків, ще 2008 року застерігав: «Росія намагається використовувати етнічних росіян в Україні для дестабілізації внутрішньополітичної ситуації, тобто для погіршення умов життя в нашій країні, в тому числі й життя самих етнічних росіян. <...> Страшно сказати, проте верховний менеджмент українських центральних органів влади й досі подеколи здійснюють випускники «вищої школи КДБ» у Москві, «вищої партійної школи в Києві» тощо. <..> Брак патріотизму, незадовільна освіта, низька культура, пристрасне користолюбство, котре породжує масштабну корупцію, безсовісність - ось типові ознаки українського менеджера 3 радянським минулим. Консервація такої системи в державних інституціях становить системну загрозу національній безпеці України. Росіяни про це знають, тому й працюють головно «з людьми»... А «люди» на вершині галузевих пірамід - об'єкт особливої уваги росіян» [31].

Василь Лаптійчук також попереджав, що «сьогодні Росія має ознаки не тільки нацистської, але й терористичної держави». I ще: «За деякими ознаками, російська сторона вже розпочала перший - інформаційний - етап підготовки й проведення 
операцій на терені України, спрямованих на усунення найнекомфортніших для Кремля політиків, громадських діячів і, можливо, журналістів»[32].

У розпал російсько-грузинського конфлікту перший командувач ВійськовоМорських Сил України віце-адмірал Борис Кожин заявив: «Вихід один - негайно в НАТО! Тоді РФ буде з нами рахуватися. Або - інший шлях. Розробити новий вид озброєнь і отримати ядерний статус. I тоді ми будемо здатні себе захистити... До речі, енергетично Україна може себе облаштувати. Тільки треба розуму й політичної волі» [22].

Олександр Скіпальський висловлює стурбованість політичним протистоянням, яке $є$ загрозливим для держави, бо не зміцнює державний механізм. Генерал нагадує, що класичною формою отримання незалежності $є$ національно-визвольний рух, і стверджує, що така боротьба не обов'язково ведеться за допомогою танків і зброї, а за допомогою спеціальних технологій»[55].

У серпні 2008 року, коментуючи російсько-грузинський конфлікт, Василь Лаптійчук заявив: «На місці Президента я б готував армію до воєнного конфлікту з Росією». Думки директора Інституту Росії більш ніж актуальні: «У російському Генштабі вже є детальні карти всіх військових об’єктів в Україні, котрі підлягають знищенню в перші ж години конфлікту, є плани окупації регіонів та блокування й знищення українських військових частин. $\mathcal{\complement}$ можливість перекрити наш ефір і заповнити його російським мовленням. Власне, на наших очах відгодовуються штатні й позаштатні зрадники з числа громадян України. У Кремлі вже готові зразки відповідних заяв про «захист російських громадян» для Заходу. Україні слід звернутися до ядерних гарантів нашої безпеки за Будапештським меморандумом. Зрештою, чому б США не запропонувати дислокувати на нашій території кілька своїх баз? Це б остудило гарячих кремлівських чекістів» [33].

У своїх тодішних оцінках, які підтвердилися через десять років, Василь Лаптійчук категоричний: «Росіяни використовують українських зрадників грубо й публічно, а потім «палять» їх поодинці й цілими партіями. $<$... Росіяни не готові працювати за умов гласності й демократії. Це їх відверто дратує й суттєво знижує ефективність підривної діяльності. Росіяни бояться світла й правди. Тут, до речі, слід відзначити чи не ключову роль у забезпеченні зовнішньої безпеки України вітчизняних ЗМІ... Наша незалежність - основна загроза російським національним інтересам. Їхня головна мета в сфері зовнішньої політики - підім'яти під себе Україну, навіть якщо нашу землю доведеться розчленити. Ми є головним об'єктом зовнішньополітичних i воєнних зазіхань для росіян, тому натовська парасолька над Україною означатиме крах сотень років встановлення на нашій землі рабства азійського штибу. <..>Так що українцям, якщо ми хочемо жити в мирі, слід бути готовими до війни. Або відмовитися від власної історії, власної ідентичності, європейського майбутнього й платити орді данину та утримувати її залоги на нашій території» [34].

Володимир Безкоровайний в аналітичній статті «Суверенітет і територіальна цілісність України через призму кримських проблем» [6] проаналізував залаштункові операції Росії, спрямовані проти суверенітету України, іiі державності. Його спостереження нині багато чого прояснюють: «26 серпня 1991 року був запущений «робочий план», і свою першу офіційну заяву з відкритою погрозою стосовно кордонів робить прес-секретар Б. Сльцина П. Вощанов. Він пояснює, що заява стосується головним чином Криму, Донбасу і Північного Казахстану, які мають значний проша- 
рок росіян: «Якщо ці республіки увійдуть до складу союзу з Росією, то проблеми немає. Але якщо вони виходять, ми повинні потурбуватися про населення, що мешкає там, і не забувати, що ці землі були освоєні росіянами. Росія навряд чи погодиться віддати їх так легко». <..> У доповіді голови парламентської комісії із зовнішньої політики Росії Є. Амбарцумова було по суті оголошено «російську доктрину для СНД»: «Як міжнародно визнаний законний правонаступник СРСР Російська Федерація у своїй зовнішній політиці повинна спиратися на доктрину, що проголошує весь геополітичний простір колишнього (Радянського) Союзу сферою своїх життєвих інтересів і забезпечити розуміння і визнання світовим товариством особливих інтересів Росії в цьому просторі. Росії також належить домогтися від міжнародного співтовариства визнання їі ролі політичного й військового гаранта стабільності на всьому просторі колишнього СССР». <.. > Навіть Андрєй Козирєв, який цивілізовано ставився до політичних процесів в Україні, приєднався до «загального антиукраїнського галасу» і кваліфікував передачу Криму як «політичне рішення колишнього Політбюро», через 10 років сказав всю правду щодо України, заявивши 24 жовтня 2003 року в програмі «Свобода слова» (НТВ) під час обговорення тузлинської кризи, що «нам нужна на самом деле вся Украина, а не только Керченский пролив». <...> У Криму штучно формувався настрій до автономії і сепаратизму. <..> 3 серпня 1991 по січень 1992 року - термін, коли Київ мав можливість взяти під контроль ситуацію на ЧФ, в Криму і Севастополі, але її було втрачено, бо не було кому керувати».

У статті «Час Україні рятувати армію, щоб армія врятувала Україну» [47] Олег Романчук наголошує, що «серпневі події 2008 року в Грузії примусили Президента України заговорити про збільшення асигнувань на українське військо. Але нині ситуація ще погіршилася...Все це нагадує спланований саботаж, спрямований на ліквідацію українського війська. Армія фактично обеззброєна. На порозі професійна деградація особового складу Збройних сил, які не зможуть гарантувати безпеку держави в разі зовнішньої агресії. <..> Тому Президент України (він же Верховний Головнокомандувач Збройних сил України) має, на мій погляд, моральне право і законні підстави звернутися із закликом до українського народу розпочати збір коштів (йдеться про добровільні пожертви людей) для порятунку війська (насамперед військово-повітряних сил)... Можливо, слід відкрити спеціальний банківський рахунок, обрати Наглядову раду з числа найдостойніших фахівців, людей моральних, справжніх патріотів, яким народ довіряс, і під їхнім пильним контролем розподіляти зібрані кошти на нагальні потреби Збройних сил та оборонної промисловості».

Цей текст (повна його версія) у вигляді звернення був переданий особисто Президентові України під час його робочої поїздки до Львівській області 11 вересня 2009 року. На підставі ст. 7 ч.3 Закону України «Про звернення громадян» Секретаріат Президента України надіслав це Зверенення (№ 22/080389-13 від 17.09.09) і на розгляд Міністерства оборони України».

«Порятунок армії - військова реформа» - автор цієї статті [27] полковник у відставці Віталій Лазоркін ще 1990 року оприлюднив Концепцію створення національних Збройних Сил України, яка була реалізована упродовж 1991-1992 років. У 1993-1996 рр. він обіймав посаду заступника начальника Центрального науково-дослідного інституту Міністерства оборони України з наукової роботи, був консультантом Комітету Верховної Ради України з питань національної безпеки і оборони (1991-2009рр), брав участь у підготовці національного військового законодавства, 
розробив проекти нової військової доктрини та концепції військової реформи України. Набутий досвід дозволив йому фахово аналізувати ситуацію в ЗСУ і зробити висновк: «Маємо позбутися принципів військового управління колишнього СССР та створити власну систему оборони, яка адаптована до потреб самої України щодо забезпечення ведення ЗСУ збройної боротьби... Головнокомандувач Збройних Сил України має відповідати за рівень боєздатності Збройних Сил, а Міністр оборони - за економіку оборонного будівництва і за всебічне забезпечення Збройних Сил України всім необхідним».

«Морська піхота - боєздатна, але малочисельна» [7]. Вже першим абзацом (стислий переказ фрагменту телесюжету російського телеканалу Рен-ТВ), яким починається розповідь журналіста Анатолій Бондаренко, котрий тиждень провів в елітному окремому батальйоні морської піхоти у Феодосії, були розставлені всі крапки над «і» стосовно присутності Росії в Криму: «Конфлікт почнеться в Севастополі, де розташовані 14 тисяч військових ЧФ Росії. Їх підтримають 4 тисячі морських піхотинців з Новоросійська та 5 тисяч солдат з Кубані. Так створиться українсько-російський фронт у Криму». Натомість українські офіцери-морпіхи у розмовах з журналістом були налаштовані пацифістськи: «Не віримо, що вони будуть з нами воювати. Ми знаємо один одного, тренуємось на одних полігонах».

Через п’ять років українська морська піхота, і не лише вона, могли переконатись у протилежному...

Петро Процик, генерал-лейтенант запасу, екс-заступник начальника ГШ ЗСУ, колишній перший заступник начальника штабу ГУР аналізує проблему розташування Чорноморського флоту Російської Федерації в Севастополі. Як військовий фахівець, автор вважає, що за своїм кількісним складом і технічним станом ЧФ РФ не тільки не може бути «гарантом безпеки України», але й сам загрожує їй та її населенню, завдає щодалі більше клопотів» [43].

Сергій Грицаєнко прагне донести до українців свою добре аргументовану позицію: місце України в світі не на узбіччі цивілізації, українці не мають бути прохачами у сильних держав, а можуть і повинні бути одними з найсильніших, на володіння ядерною зброєю ми маємо повне право як й інші члени «ядерного клубу» [9]. Питання боротьби за національну державу є безперечним пріоритетом. Автор переконаний, що головне в політичній складовій ядерного питання - усвідомлення того, що ніхто не зацікавлений в сильній Україні, крім самої української нації. Тому треба усвідомити, що Україні не слід «створювати» ядерну зброю - вона вже створена за участю українців. Тож йдеться про обрання напряму розвитку ядерної програми, який був би реалістичним для втілення та забезпечував розв'язання проблемних питань національної безпеки (загрози з боку недружніх ядерних держав, терористичних угруповань тощо).

Генерал-лейтенант Олекандр Скіпальський у великому публіцистичному матеріалі «Без щита і меча» ділиться своїм життєвим досвідом, розповідає про цікаві й повчальні епізоди своєї професійної діяльності, зокрема про боротьбу з корупцією у вищих ешелонах влади [56].

Генерал-лейтенант запасу Петро Процик відзначає, що «в свідомості української політичної еліти немає державницької ідеї, або ж вона не превалює» [42]. Відтак резюмує: «Таке гірке спостереження особливо рельєфно підтверджується ставленням влади до захисту та оборони держави. Наша ж армія впродовж усіх років, 
за усіх президентів, урядів і міністрів фінансів (навіть запеклих патріотів) фінансувалась практично вполовину від мінімальної потреби, тож фактично втратила боєздатність... Влада по-волюнтаристськи змінила безпекову політику, проголосила ефемерний «позаблоковий статус». <.. >На прикладі законопроекту про безпідставне, нічим не обгрунтоване скорочення українського війська та інших дій влади, що фактично роззброюють державу, можемо у черговий раз констатувати: нинішні «професіонали» узурпували владу далеко не для того, щоб розбудовувати Україну».

Віталій Лазоркін звертає увагу на те, що «6 грудня 2011 року - 20-та річниця Дня Збройних сил України. Це державне свято в Україні відзначається надто скромно і не досить широко, як звичайне професійне свято, що свідчить про непрестижність професії захисника Вітчизни у нашому суспільстві. <...> Жоден з Президентів України як Верховний Головнокомандувач Збройних сил не доклав належних зусиль до виробництва нових зразків озброєння» «Збройні Сили України: 1991-2011» [28].

У статті «Чи можуть Збройні сили України гарантувати iї безпеку?» [14] полковник запасу Петро Костюк, Голова Львівської обласної організації Спілки офіцерів України зазначає: «Проголошення української державності не спонукало політичну та військову еліту до зміни способу мислення, а також бачення проблем свого становища, власного погляду на історію рідного краю. <..> Є нерозуміння військово-політичних питань, стратегії і національної безпеки. Через це немає налаштованості на реалізацію національних інтересів. <..> Ця ментальність перейшла через конкретних ㄲï носіїв, які самі зголошувались на високі посади в ЗСУ, використавши кон'юнктуру моменту, але при цьому не бажали нічого змінювати. Це становить певну загрозу збереженню суверенітету України. Тому, власне, потрібна зміна способу мислення керівників цих структур щодо відродження та творення українських військових традицій».

Петро Процик намагається привернути увагу владних структур до проблем 3СУ: «Нині наша країна не захищена ні економічно, ні політично, ні інформаційно, духовно, ні військовою потугою... Брак політичної волі вищих керівників України до зміцнеення обороноздатності держави спричинила падіння її до критичної межі. Наші Збройні Сили, отримуючи вкрай недостатнє фінансування, фактично втратили боєздатність» [44].

У статті «Що потрібно українській державі: кадетський корпус чи юнацька школа?» [48] Олег Романчук наголошує, що «Українській державі потрібні герої, які б віддзеркалювали не чужинецьку ментальність, а власну, українську. Тим часом знову і знову експлуатується століттями апробована система російських імперських символів». Автор звертає увагу на підписаний 2011 року Президентом України, Верховним Головнокомандувачем ЗСУ Віктором Януковичем Указ про створення Сумського «Кадетського корпусу» і нагадує, що кадети Миколаївського «Кадетського союзу» встановили пам'ятник Алєксандру Суворову, а члени Одеського «Кадетського союзу» - загиблим кадетам та офіцерам і відтворили історичний Прапор Одеського Великого князя Костянтина Костянтиновича кадетського корпусу. «Замість формування власних образів й сенсів, Українська держава мовчки споглядає, як цією проблемою займається п’ята колона, творячи так званий «русскій мір», - констатує Олег Романчук. - Пропагування російсько-імперської символіки - не безневинні забави. Змінити свідомість молодого покоління українців, духовно дезорієнтувати його - надзавдання ворогів Української держави». 
Петро Костюк у статті «Збройні сили України: у пошуках нитки Аріадни?» [15] застерігає: «Не може творитись сучасна модель збройних сил окремо від решти суб’єктів забезпечення обороноздатності держави. Зменшена чисельність ЗСУ, не підкріплена новітніми озброєннями, без перерозподілу функцій і завдань, а найважливіше відповідальності поміж іншими суб'єктами забезпечення обороноздатності держави та їх нормативно-правового закріплення - це явний неуспіх».

Петро Костюк $є$ автором і статті «Збройні сили України: небезпечний «марафон» [16], в якій висловлює стурбованість так званими «реформами» у Збройних Силах України, безглуздими скороченнями, які там проводяться: «Досвід останніх років так званих реформ, зокрема Повітряних Сил вказує, що йдеться не про зміцнення обороноздатності держави, а про механічне скорочення. Результат очевидний - заволодіння певними бізнесовими угрупуваннями інфраструктурою, нерухомістю та іншими активами Збройних Сил, на яких можна добряче нажитися в Одесі, Львові, Вінниці».

Відомий публіцист Ігор Лосєв у статті «Як армію України робили недієздатною» [30] лише підтвердив неодноразові перестороги авторів «Універсуму» щодо фактичного саботажу ЗСУ з боку керівництва Української держави: «Події у Криму, а тепер ще й у Донбасі, показали, що силові структури України виявилися неефективними і нефункціональними. $<\ldots>$ Армія так і залишилася уламком радянської армії, дітищем російсько-радянської військової традиції. Це пов'язано також із тим, що у процесі виховної роботи дуже активно акцентували на так званій «спільній» радянсько-російській воєнній історії і героїці, залишаючи на маргінесі власне українське, постійно нав'язуючи наслідування зразків СРСР і Росії. $<\ldots>$ Силові структури України перебували в полоні ідеології «дружби з Росією» <...> Навіть спецслужби надто тісно співпрацювали, настільки тісно, що за часів Януковича і шефа СБУ Якименка патріотична громадськість України почала єхидно називати СБУ так: ФСБ (У). <..> Ідеологічно розкладена армія не здатна воювати. <..> Тому нині треба робити фундаментальні висновки, у першу чергу щодо докорінної зміни системи виховання особового складу армії та інших силових структур. Все має у цій сфері будуватися на вихованні українського патріотизму».

У статті «Як перемогти в інформаційній війні?» [49] Олег Романчук звертає увагу на виступ 12 березня 2014 року заступника секретаря Ради національної безпеки i оборони Вікторії Сюмар, яка визнала неготовність і непристосованість українських ЗМІ до інформаційної війни. Автор ставить риторичні питання: «Чи беруть до уваги високопосадовці Закони України «Про інформацію», «Про державну таємницю» тощо? Чи знають «професіонали», що опинились біля владного стерна, про існування напрацьованих попередниками указів та постанов, які регулюють конкретні дії чиновників, службовців щодо захисту інформації? Чи знайоме їм таке поняття, як «керування ризиком»- об'єктивна оцінка реальності небезпеки з одного боку і вжиття необхідних контрзаходів з іншого?» Олег Романчук звертає увагу на те, що центральні телеканали України продовжують виконувати роль своєрідних пропагандистських центрів сепаратистів. Автор акцентує: «Сьогодні не може бути жодної мови про якусь збалансованість подачі інформації. Найперш має спрацьовувати патріотизм, фаховість і відповідальність перед народом, перед державою. Власники телеканалів також мають дотримуватись цих принципів.. Треба вести наступальну історичну пропаганду. Для безпеки Української держави зараз це надважливо». 
Петро Костюк у статті «Маємо якнайшвидше приєднатися до НАТО» [17] підкреслює, що Росія чинитиме все можливе і неможливе для дестабілізації ситуації в Україні. Думка автора по-військовому чітка й конкретна: «Для того щоб захистити територіальну цілісність, Україна має стати членом НАТО. Достатній рівень обороноздатності може бути досягнутий членством нашої держави тільки у військово-політичному союзі завдяки принципу взаємодопомоги... Якщо ж не НАTO, то треба починати процес набуття статусу ядерної країни. Ми вже переконались, що зупинити агресію при наявному озброєнні за умови невиконання підписантами Будапештського меморандуму неможливо. Засобам масової інформації та недержавним організаціям треба здійснювати тиск на уряд, щоб він розпочав серйозну інформаційну кампанію. Маємо розпочати якісну й чесну суспільну дискусію. Сьогодні головне єдність в досягненні мети, велика інформаційна та комунікаційна робота».

Володимир Лановий у статті «Війна як плата за свободу» [29] нагадує, що для Кремля головне - знищення України як самостійної держави або ж існування під протекторатом Москви. «Усвідомлення цього, - пише автор, - відбулося із запізненням. Держава виявилася неготовою вести бойові дії».

В’ячеслав Гусаров, аналітик ІАЦ РНБОУ, підкреслює, що стримані інформаційно-психологічні методи Кремля були змінені жорсткими військовими операціями на території України і дуже схоже, що Росія зацікавлена продовжувати це виснажливе протистояння. На думку автора, гібридна війна буде перенесена на всю територію України у вигляді диверсійних операцій. Відтак «Україна потребує створення системи протидії поширенню панічних настроїв в суспільстві. Для цього необхідний постійний моніторинг морально-психологічного стану населення в усіх регіонах держави» [10].

Директор Центру дослідження армії, конверсії та роззброєння Валентин Бадрак аналізує альтернативні можливості та асиметричні дії в протистоянні з набагато сильнішим у військовому плані ворогом [2]. Він же в інтерв’ю журналові нагадує, що Росія ніколи не приховувала, що має претензії до України, що українські військові фахівці та експерти говорили, що РФ готується до війни, але нічого не було зроблено і Україна підійшла до війни неготовою [3].

Петро Костюк у статті «Гібридна війна» чи «гібридний мир»? [18] нагадує про допущені керівництвом держави прорахунки: «Збройна агресія проти України стала результатом не лише політики очолюваних Владіміром Путіним імпершовіністів, а й стратегічних прорахунків та безвідповідальності української владної еліти упродовж усіх років незалежності. У часи Леоніда Кучми було ліквідовано Національну гвардію (створена 1991 року) - боєздатне, багатофункціональне військове формування, укомплектоване патріотично налаштованими і досвідченими офіцерами. Ця структура мала стати ядром модерних Збройних сил. Натомість Кучма віддав перевагу формуванню ЗСУ методом скорочення гігантського уламка радянської армії на території України. Зменшення фінансування Збройних сил унеможливлювало їх оснащення сучасною військовою технікою та озброєнням. За президентства Віктора Ющенка недофінансування Збройних сил України тривало, а за часів Віктора Януковича завершилося руйнацією всього сектору національної безпеки. Деградація армії, флоту, зовнішньої розвідки та контррозвідки, СБУ, РНБОУ відбувалася не без участі російських спецслужб та їхніх агентів, інфільтрованих у структури держав- 
ного управління всіх рівнів... На жаль, принципова оцінка російської агресії на рівні керівництва Української держави досі відсутня».

Польський експерт і журналіст Міхал Козак на експертному форумі «Крим у контексті безпеки Чорноморського регіону: проблеми та перспективи», який відбувся у Стамбулі 3-4 листопада 2015 року, висловив ряд слушних думок: «Замість ілюзій треба прийняти правду - Росії та росіян із європейськими цінностями не по дорозі. Дивлячись на історію цієї країни, видно, що ніколи ій з ними по дорозі не було, і на даний момент немає ніяких передумов, що колись буде. Росії немає місця в політиці регіонального співпраці через те що цінності, які $є$ загальними для країн регіону мирне співробітництво і взаємовигідний розвиток в умовах демократії, це для неї поняття і цінності чужі... Величезною проблемою $є$ дестабілізуюча політика української влади стосовно окупованого Криму - це фактично підтримка російської окупації - через поставки електроенергії за ціною нижчою закупівельної - у підсумку є не просто підтримка, але безпосереднє спонсорство окупації, вчинене Києвом. Це незрозуміла ідея так званої вільної економічної зони «Крим». Це невключення в український списку санкцій головних російських банків зі списку санкцій США» [23].

Віктор Шишкін, перший Генеральний прокурор незалежної України, екс-суддя Конституційного суду України, стверджує, що «поведінка української влади як на Банковій, так і на Грушевського, є або дурістю або колаборацією» [61].

Демобілізований старший сержант ЗСУ, екс-спікер ВР України Руслан Кошулинський розповідає про службу у війську та проблеми України в сучасній війні: «Найперша перемога, яку нам треба здобути, - це перемога в людських головах... Вже сьогодні зрозуміло, що Москва нас так просто не відпустить. Війна буде довгою та виснажливою. Україна повинна збудувати власну армію на зразок Ізраїльської чи Швейцарської. Наші ЗСУ мають стати потужними. Допоки цього не буде, нас намагитимуться шматувати і далі» [24].

«Із військового бюджету розкрадають щонайменше чверть» - це винесена у заголовок інтерв'ю одна з думок відомого волонтера і військового експерта Юрія Касьянова, який вважає, що реформу в ЗСУ навіть не починали [13]. На його переконання, професійна армія має бути з людей, які розуміють, що йдуть захищати Батьківщину й хочуть це робити. Волонтер дуже конкретний: «Головна причина, чому ми досі не перемогли, - страх. Російські контингенти увійшли неподалік Іловайська, а Гелетей, тодішній міністр оборони, навіть не знав, що ми в оточенні. Побігли підписувати Мінськ-1, а потім Мінськ-2. Боялися розгрому й того, що противник дійде до Дніпра...Якби тоді наша влада не злякалася, у Росію пішов би потік трун. Але нами керують не лідери й не полководці, а жадібні бізнесмени».

Петро Костюк порушує тему десовєтизації Збройні Сили України як одного 3 найважливіших соціальних інститутів країни [19]. Автор звертає увагу на те, то попри агресію Росії Національна гвардія України та інші силові структури нашої держави продовжують перебувати в інформаційному полі пріснопам'ятного СССР. Костюк наголошує: «Виконання закону про декомунізацію залежить не тільки від політичної волі влади, а й від прагнення суспільства до очищення. В українському контексті це і очищення від російських колоніальних цінностей,оскільки колоніальна комуністична ідеологія і практика в Україні носила яскраво виражений російський імперський характер». П. Костюк наводить приклади нігілістичного ставлення керівницта ЗСУ до історії українського війська: у Національному універ- 
ситеті оборони України донині функціонує аудиторія № 222 імені фельдмаршала I. Ф. Паскевича (як стало відомо, іменна табличка на честь російського полководця вже знята. - В. Р.), а при вході до ліцею імені Івана Богуна бовваніє пам'ятник російському генералісимусу О. Суворову. Автор звертає увагу на семіотичний рудимент СРСР - нумерацію українських військових частин та установ, запроваджену ще в часи Совєтського Союзу.

У статті «Збройним силам України чверть століття» [20] Петро Костюк позитивно оцінює зміни у підходах до формування засад державної політики України, викликані розвитком подій у 2014 році: скасування позаблокового статусу, зупинення виконання заходів Державної комплексної програми реформування і розвитку ЗСУ на період до 2017 року, що не відповідає сучасній воєнно-політичній обстановці, затвердження Стратегії національної безпеки України, нової редакції Воєнної доктрини України та Концепції розвитку сектора безпеки і оборони України, а також визначення курсу на європейську інтеграцію та наміру вступу до НАТО. Разом з тим автор відзначає, що Українська держава остаточно не визначились, чого слід прагнути в царині національної безпеки і оборони.

У розлогому дослідженні «Хто розв’яже інформаційний «Гордіїв вузол» Збройних Сил України?» [21] Петро Костюк резонно зазначає, що не лише зброя визначає переможців у війні: «Величезне значення мають настрої, які панують у суспільстві, те, наскільки суспільство ладне давати відсіч ворогові. Росіяни анексували Крим i окупували частину Донбасу не тільки через те, що Збройні Сили та силові структури були поруйновані, а й через те, що тут вдалося насадити «русский мир». <..> Нинішня російсько-українська війна — війна світоглядна. Або утверджується українська проєвропейська ідентичність, або відроджується просовєтська, проросійська ідентичність. < . .> «Русский мир» - агресивна ідеологія Кремля, що заперечує право українців на власну історію, державність, навіть мову. Актуальним залишається питання функціонування державної мови у ЗС України та інших військових формуваннях. Російська мова продовжує лунати не лише в бойових військових частинах, а й у військових навчальних закладах і в наукових установах Збройних Сил України».

В інтерв’ю з Галиною Плачиндою генерал Олекандр Скіпальський з погляду розвідника пояснює причини нинішніх негараздів в Україні: «3 початком перебудови в Росії передбачили можливиq розпад Радянського Союзу і уже тоді верхівка Комітету держбезпеки, побачивши рух оцей в республіках до самостійності, почала готувати спеціальні плани. Наприклад, Головне розвідувальне управління вже тоді підготувало таємний підручник, який називався «Дестабілізація режимів іноземних країн за досвідом війни в Афганістані». Перепідготовку офіцерів у складі невеликих груп, починаючи з 1986 року, вели настільки успішно, що і сьогодні деякі випускники цих курсів працюють в Україні на різних ділянках. Проведення російських спецоперацій $\epsilon$ сьогодні найбільшою загрозою з боку Росії. Тому що суспільство їх не бачить, їх може побачити тільки спеціаліст... Але ж нам усім треба пам'ятати, що війна проти України ведеться не тільки вдовж лінії розмежування з окупованими територіями. Сьогодні лінія фронту з Росією пролягла через НБУ, через Укроборонпром. Лінія фронту проходить по Нафтогазу, по облгазам, по СБУ, по Міністерству оборони, через Генпрокуратуру - тобто, боротьба ведеться тотальна. А ми ці структури не наповнюємо професіоналами, навпаки... » [57]. 
«Як захистити Україну в умовах війни» [58] - роздуми генерал-лейтенанта Олександра Скіпальського, «підготовлені переважно для добровольців, людей, які по суті голіруч кинулись захищати Україну від лютого ворога; для волонтерів, які почали їм допомагати, поки Турчинов, Яценюк, Парубій, Пашинський думали-гадали, як не дратувати Путіна, аби не спровокувати його на ще більшу агресію». Автор рідкреслює, що «матеріали підготовлені як узагальнення знань тих, кому добре відомі методи роботи спецслужб Росії».

3 початком російсько-українського військового протистояння редакція «Універсуму» підготувала спеціальне число журналу [№5-6, 2014], оприлюднивши в ньому найліпші, з погляду членів редколегії, матеріали військової тематики, які в різний час друкувалися на сторінках видання.

Була, зокрема, вміщена стаття шеф-редактора «Універсуму» Олега Романчука «Збройні сили України: міф чи реальність?» [50], котра вперше побачила світ 1992 року в часописі «Сучасність» (ч.11). Вже тоді автор застерігав: «Нинішня пацифістська позиція України може призвести (як і в 1918 році) до вельми драматичних наслідків. Адже неозброєним оком видно, як під імперські знамена потяглися, здавалось би, кращі представники російської демократичної інтелігенції. Навіть міністр закордонних справ Росії Андрєй Козирєв був змушений констатувати: «То, что происходит сейчас у нас (в Росії. - О. Р.), - похоже на 1933 год в Германии, когда часть демократов стала переходить на националистические позиции...». Вже тоді Олег Романчук пропонував запровадити нові однострої та знаки розрізнення для ЗСУ, ним були навіть виготовлені відповідні ескізи, оприлюднені на сторінках багатьох українських періодичних видань, в тому числі й «Голосу України». Чекати довелося чверть століття...

У статті автор нагадує, що США не взяли на себе жодних гарантій щодо безпеки України, яка навіть тактичну ядерну зброю передала північно-східному сусідові, відомого своєю непередбачуваною поведінкою, забувши поетичне застереження Лесі Українки: «Вкраїна бачила не раз, як тії закоханці під вечір забували все, про що співали вранці...»

Олег Романчук цитує погрозу впливового лідера опозиції в російському парламенті тих років Сергія Бабуріна, висловлену в розмові з Надзвичайним і Повноважним Послом України в Росії Володимиром Крижанівським: «Либо Украина вновь воссоединится с Россией, - либо - война» [11]. I тільки-но вражений Посол взявся говорити про співпрацю двох незалежних держав, як у відповідь почув: «Нет. И если не произойдет новое воссоединение, конфликты между Украиной и Россией будут всегда».

Ще тоді, на початку 90-х минулого століття, Олег Романчук звертав увагу на те, як підливали масла у вогонь російські мас-медіа, зокрема спеціальні кореспонденти «Собеседника»: «Россия справедливо считает Крым своим - потом и кровью многих поколений русских людей полита дорога к нему и он сам. <..> А пока что украинские власти делают одну ошибку за другой, раз за разом ставя ножку на югославскую тропинку: объявили и Крым, и Севастополь своими... Кто и с кем готовится воевать? Началось все с Черноморского флота - вспомните, какое всеобщее возмущение охватило тогда всех в России: как так, на нашу гордость и славу наложил руку Кравчук! $<\ldots>$ Итак, если Россия не отступится от Крыма, между нею и Украиной в самом недалеком будущем начнется вооруженный конфликт. Это очевидно» [59]. 
Автор зафіксував й виразно антиукраїнські пасажі в газеті Верховної Ради Криму «Крымские новости» - Росія, мовляв, поверне собі не тільки Крим, але й «одеські, миколаївські, херсонські, криворізькі, харківські та інші землі й багато іншого, що споконвіку належало їй» [25]. Автором були відзначні й провокаційні солдафонські погрози міністра оборони Росії генерала Грачова: «Если будут ущемлены честь и достоинство русского населения в любом регионе, не только в Чечне, мною будут приняты самые решительные меры, вплоть до ввода войск для недопущения дискриминации, нападок и других хулиганских выпадов по отношению к русскому населению» [12]...

Цим числом журналу [№5-6, 2014] редакція «Універсуму» нагадала читачам про послідовну позицію видання в обороні ЗСУ, оскільки добре розуміла, що «для ефективного функціонування системи-суспільства має бути постійно увімкнутий канал зворотного зв'язку, дію якого забезпечують гласність, демократичні принципи, вільна преса» [51]. I саме тому «впродовж двох десятиліть «Універсум» аналізував, попереджав, застерігав, звертав увагу: хто не хоче годувати власне військо, годуватиме чуже. Та належних висновків так звана українська влада не робила...» [№5-6, 2014. - C.9].

Висновки. Серед основних проблем, пов'язаних із будівництвом ЗСУ, які порушував «Універсум», - національна і воєнна безпека, військова розвідка, реформування та розвиток Збройних сил України, Військово-Морських Сил ЗС України, Національної гвардії України, Державної прикордонної служби України, роль НАТО як військово-політичного союзу, гуманітарні аспекти оборонної сфери, воєнна та військова історія України, проблема декомунізації ЗСУ, а з 2014 року ретельний аналіз причин і перебігу російсько-української війни, дослідження її інформаційної складової.

«Універсум» критично і принципово оцінював діяльність керівництва держави у сфері реформування 3СУ, але це була водночас і конструктивна критика. В публікаціях часопису незмінно домінувала головна ідейно-концептуальна засада військової тематики - ідея української державності.

Процес реформування Збройних Сил України тісно пов'язаний з економічними та суспільно-політичними чинниками. На підвищення боєздатності ЗСУ може позитивно вплинути і компетентна комунікація. Треба шукати шляхів доведення об'єктивної інформації до керівництва держави. Належне використання потенціалу цивільних ЗМІ для інформування суспільства про життєдіяльність ЗСУ, а також для компетентного й ефективного зв'язку з державними чинниками допоможе активному будівництву та функціонуванню українського війська.

Збройним силам України має бути притаманна чітка проукраїнська позиція. Для їі утвердження вітчизняні мас-медіа повинні всіляко утверджувати й популяризувати серед військових національну ідентичність, плекати почуття патріотизму, бо саме ці надважливі компоненти державницького будівництва можуть остаточно виокремити українців з культурно-політичного полону екс-метрополії, все ще переобтяженої імперськими комплексами.

\section{REFERENCES}

1. Андресюк Б. Військова організація України: цивільний демократичний контроль [5-6, 2005] C.10-11. 
2. Бадрак В. Військо: розставити крапки над «і» / В. Бадрак // Універсум. - 2014. №9-10. - С.25-26.

3. Бадрак В. Українській армії треба 5-7 років, щоб могти протистояти російській воєнній машині / В. Бадрак // Універсум. - 2014. - №9-10. - С.23.

4. Безкоровайний В. Угоди про Чорноморський флот мають бути переглянуті України / В. Безкоровайний // Універсум. - 2005. - №7-10. - С.14-15.

5. Безкоровайний В. Чорноморський флот Росії в Україні / В. Безкоровайний // Універсум. - 2005. - №7-10. - С.16-21.

6. Безкоровайний В. Суверенітет і територіальна цілісність України через призму кримських проблем / В. Безкоровайний // Універсум. - 2008. - №11-12. - С.12-21.

7. Бондаренко А. Морська піхота - боєздатна, але малочисельна / А. Бондаренко // Універсум. - 2009. - №11-12. - С.35-36.

8. Гривачевський Б. «Морський бриз-97» / Б. Гривачевський // Універсум. - 1997. №9-10. - C.10-13.

9. Грицаєнко С. Ядерне питання: 18 років безхребетності / С. Грицаєнко // Універсум. -2009 . - №11-12. - С.37-40.

10. Гусаров В. РФ: диверсії проти України / В. Гусаров // Універсум. - 2014. №9-10. - С.28-29.

11. Известия. $-1992 .-27$ мая.

12. Известия. $-1992 .-6$ июля.

13. Касьянов Ю. Із військового бюджету розкрадають щонайменше чверть / Ю. Касьянов // Універсум. - 2016. - №5-6. - С.31-32.

14. Костюк П. Чи можуть Збройні сили України гарантувати її безпеку? / П. Костюк // Універсум. - 2012. - №1-2. - С.16-21.

15. Костюк П. Збройні сили України: у пошуках нитки Аріадни? / П. Костюк // Універсум. - 2013. - №11-12. - С.44-48.

16. Костюк П. Збройні сили України: небезпечний «марафон» / П. Костюк // Універсум. - 2014. - №1-2. - С.26-27.

17. Костюк П. Маємо якнайшвидше приєднатися до НАТО / П. Костюк // Універсум. - 2014. - №5-6. - С.47-48.

18. Костюк П. «Гібридна війна» чи «гібридний мир»? / РП. Костюк // Універсум. 2016. - №1-2. - С.31-33.

19. Костюк П. Десовєтизація Збройних сил України як чинник творення національного війська в Україні / П. Костюк // Універсум. - 2016. - №7-8. - С.7-12.

20. Костюк П. «Збройним силам України чверть століття» / П. Костюк // Універсум. - 2016. - №11-12. - C.4-8.

21. Костюк П. Хто розв’яже інформаційний «Гордіїв вузол» Збройних Сил України? / П. Костюк // Універсум. - 2017. - №7-8. - С.10-17.

22. Кожин Б. Вихід один - негайно в НАТО! / Б. Кожин // Універсум. - 2008. №7-8. - С.25-26.

23. Козак М. Анексія Криму і європейська безпека: польський погляд / М. Козак // Універсум. - 2015. - №11-12. - С.13-15.

24. Кошулинський Р. Найперша перемога, яку нам треба здобути, - це перемога в людських головах / Р. Кошулинський // Універсум. - 2016. - №5-6. - С.33-34.

25. Крымские известия. $-1992 .-27$ мая. 
26. Лавренюк О. Хто розвалює нашу армію? / О. Лавренюк // Універсум. - 1996. №3-4. - С.13-14.

27. Лазоркін В. Порятунок армії - військова реформа / В. Лазоркін // Універсум. 2009. - №11-12. - С.30-32.

28. Лазоркін В. Збройні Сили України: 1991 - 2011 / В. Лазоркін // Універсум. - 2011. №11-12. - С.26-29.

29. Лановий В. Війна як плата за свободу / В. Лановий // Універсум. - 2014. - №9-10. C.20-222.

30. Лосєв І. Як армію України робили недієздатною / І. Лосєв // Універсум. - 2014. №5-6. - C.43-44.

31. Лаптійчук В. До питання взаємної залежності України й Росії в галузі політичних відносин / В. Лаптійчук // Універсум. - 2008. - №5-6. - С.7-16.

32. Лаптійчук В. «Mein Kampf» Владіміра Путіна, або до питання двосторонніх зоологічних відносин / В. Лаптійчук // Універсум. - 2008. - №7-8. - С.10-16.

33. Лаптійчук В. У російському генштабі вже є детальні карти всіх військових об'єктів в україні, котрі підлягають знищенню / В. Лаптійчук // Універсум. - 2008. №9-10. - С.20.

34. Лаптійчук В. Росіяни використовують українських зрадників грубо й публічно, а потім «палять» їх поодинці й цілими партіями / В. Лаптійчук // Універсум. 2008. - №9-10. - С.16-19.

35. Морозов К. Я щиро повірив в ідею державної незалежності України / К. П. Морозов // Універсум. - 1994. - №1-2. - С.25, 33-34.

36. Морозов К. Політична визначеність здійснить Україну як державу / К. П. Морозов // Універсум. - 1995. - №11-12. - С.8-10.

37. Морозов К. Актуальні проблеми військової реформи / К. Морозов // Універсум. 1996. - №3-4. - С.8-12.

38. Морозов К. Система європейської безпеки і національні інтереси України / К. Морозов // Універсум. - 2002. - №9-10. - С.12-20.

39. Олексіїв М., Козакевич О. Тиха війна / М. Олексіїв, О. Козакевич // Універсум. 1996. - №3-4. - С.7-8.

40. Павличко Д. Костянтин Морозов: «Моя українізація» / Д. В. Павличко // Універсум. - 2014. - №9-10. - С.25, [9-10, 2014]. С.46-48.

41. Пирожков С. Актуальні проблеми реформування сфери безпеки і оборони України / С. Пирожков // Універсум. - 2005. - №7-10. - С.12-13.

42. Процик П. Нерідне військо рідної держави, або грошей нема / П. Процик // Універсум. -2011. - №9-10. - С.32-33.

43. Процик П. Передвиборна політика та невігластво / П. Процик // Універсум. 2009. - №11-12. - С.33-34.

44. Процик П. Обеззброєна країна / П. Процик // Універсум. - 2012. - №3-4. - С.3-4.

45. Прядко В. Під прапором Сагайдачного і Хоткевича / В. Прядко // Універсум. 1998. - №1-2. - С.29-31.

46. Прядко В. Ще один шанс примирення / В. Прядко // Універсум. - 2000. - №3-4. C.26-27.

47. Романчук О. Час Україні рятувати армію, щоб армія врятувала Україну / О. Романчук // Універсум. - 2009. - №9-10. - С.1-2. 
48. Романчук О. Що потрібно українській державі: кадетський корпус чи юнацька школа? / О. Романчук // Універсум. - 2012. - №5-6. - С. 25-27.

49. Романчук О. Як перемогти в інформаційній війні / О. Романчук // Універсум. 2014. - № 5-6. - С. 45-46.

50. Романчук О. Збройні сили України: міф чи реальність? / О. Романчук // Універсум. - 2014. - № 5-6. - С. 10-17.

51. Романчук О. К. Системний аналіз у журналістиці : навч. посіб. / О. К. Романчук.Львів: Універсум, 2008. - С. 262.

52. Селюк О. Третє роззброєння / О. Селюк // Універсум. - 2004. - №7-9. - С. 18-19.

53. Скіпальський О. Хлопчики вірять, що вони «зробили майдан», і тепер їм усе дозволено / О. Скіпальський // Універсум. - 2005. - №7-10. - С. 26-27.

54. Скіпальський О. Україна-XXI: виклики і змагання / О. Скіпальський // Універсум.- 2005. - №7-10. - С. 22-25.

55. Скіпальський О. Без європейської колективної безпеки Україна не виживе / О. Скіпальський // Універсум. - 2008. - №9-10. - С. 21-22.

56. Скіпальський О. Без щита і меча / О. Скіпальський // Універсум. - 2009. №11-12. - C.45-47; №1-2, 2010. - C.40-41.

57. Скіпальський О. Тільки кругова оборона збереже нас і збереже Україну / О. Скіпальський // Універсум. - 2018. - №1-2. - С.31-35 (інтерв’ю взяла Галини Плачинда, видання МИР).

58. Скіпальський О. Як захистити Україну в умовах війни / О. Скіпальський // Універсум. - 2018. - №3-4. - С.14-19.

59. Собеседник. - 1992. - № 22.

60. Требін М. Принципи життєдіяльності Збройних сил України / М. Требін // Універсум. -1999 . - №7-8. - С.19-22.

61. Шишкін В. Будь-які зміни Конституції означатимуть, що у нас немає війни і Путін - не агресор! / В. Шишкін // Універсум. - 2016. - №5-6. - С.36. 


\title{
THE UKRAINIAN MILITARY THEMATICS \\ IN THE UNIVERSUM MAGAZINE (1993-2018)
}

\author{
Viktoriya Romanchuk \\ The all-Ukrainian Journal of Political Science, Futurology, Economics, \\ Science and Culture «Universum», \\ Box 2994, 79017, Lviv, Ukraine \\ e-mail: viktoriva.romanchuk7@gmail.com
}

In the article there are analyzed the publications of the authors of the magazine, who during twenty-five years covered various problems of the building of the Armed Forces of Ukraine in a specific form and in a real time.

The article allows a better understanding the complex process of the revival of our owntroops and their role in the establishment of the Ukrainian state on the politicalmap of the world - the Armed Forces of Ukraine traditionally act as the initiator of modernization of the domestic economy, stimulate scientific progress in the country as well as the patriotic education of its citizens.

The article helps to realize the difficulties and obstacles that should be overcame by the patriotically-minded officers and generals, active representatives of the public, who understood the vital role and the value of the troops to strengthen the country's defense capability, consolidation of the authority of the Ukrainian state.

The article reproduces the main milestones of the formation of the Armed Forces, in particular their participation in the international military actions and exercises, peacekeeping operations.

The main problems, which prevented an effective implementation of the military reform, are highlighted - they largely led to the loss of the military efficiency of theArmy: at the beginning of the year 2014, the authorities still did not realize thatthe territory of their own country will become a costly payment for Ukraine's accession tothe European structures.

The article analyzes the reasons that made the military-politicalconflict with Russia possible, thereby confirming the final need for an urgent creation of the combat-capable Armed Forces, about which the «Universum» magazine constantly reminded in its publications during 1993-2018. It is possible only to ascertain that the threats of the future were identified in the publications correctly. But nevertheless the attempts to persuade the Ukrainian leadership to prepare properly for a possible external aggression had failed.

In the article the relevant questions and problems of the military safety of the Ukrainian state, of the military politics, of the reformation of the military forces of Ukraine are analyzed all these issues were cleared enough by the famous and well-known specialists on the pages of the magazine during the last 25 years.

The article may be useful for the researchers of the recovery period of Ukrainian statehood during the XX-XXI centuries, as well as for the patrioticeducation of the Ukrainian youth.

Key words: Armed Forces, combat capability, military doctrine, crisis, reform, disarmament. 